\title{
Universiteit
}

Leiden

The Netherlands

\section{Structure, cytotoxicity, and DNA-cleavage properties of the complex} [CuII(pbt)Br2]

Maheswari, P.U.; Ster, M. van der; Smulders, S.; Barends, S.; Wezel, G.P. van; Massera, C.; ... ; Reedijk, J.

\section{Citation}

Maheswari, P. U., Ster, M. van der, Smulders, S., Barends, S., Wezel, G. P. van, Massera, C., ... Reedijk, J. (2008). Structure, cytotoxicity, and DNA-cleavage properties of the complex [CuII(pbt)Br2]. Inorganic Chemistry, 47(9), 3719-3727. doi:10.1021/ic702306f

Version: Publisher's Version

License: $\quad$ Licensed under Article 25fa Copyright Act/Law (Amendment Taverne)

Downloaded from: https://hdl.handle.net/1887/3210244

Note: To cite this publication please use the final published version (if applicable). 


\title{
Structure, Cytotoxicity, and DNA-Cleavage Properties of the Complex [Cu"l(pbt)Br${ }_{2}$ ]
}

\author{
Palanisamy Uma Maheswari, ${ }^{\dagger}$ Martijn van der Ster, ${ }^{\dagger}$ Simon Smulders, ${ }^{\dagger}$ Sharief Barends, ${ }^{\dagger}$ \\ Gilles P. van Wezel, ${ }^{\dagger}$ Chiara Massera, ${ }^{\ddagger}$ Sudeshna Roy, ${ }^{\dagger}$ Hans den Dulk, ${ }^{\dagger}$ \\ Patrick Gamez, ${ }^{\dagger}$ and Jan Reedijk ${ }^{\star, \dagger}$
}

Leiden Institute of Chemistry, Leiden University, P.O. Box 9502, 2300 RA, Leiden, The Netherlands, and Dipartimento di Chimica Generale ed Inorganica, Chimica Analitica, Chimica Fisica, Università degli Studi di Parma, Viale G. Usberti 17/A, 43100, Parma, Italy

Received November 23, 2007

\begin{abstract}
The reactions of the ligand 2-(2-pyridyl)benzthiazole (pbt) with $\mathrm{CuBr}_{2}$ and $\mathrm{ZnCl}_{2}$ in acetonitrile produce the complexes $\left[\mathrm{Cu}(\mathrm{pbt}) \mathrm{Br}_{2}\right](\mathbf{1})$ and $\left[\mathrm{Zn}(\mathrm{pbt}) \mathrm{Cl}_{2}\right](\mathbf{3})$, respectively. When complex 1 is dissolved in DMF, complex 2 is obtained as light-green crystals. The reaction of pbt with $\mathrm{CuBr}_{2}$ in $\mathrm{DMF}$ also yields the complex [Cu(pbt) $\left.\mathrm{Br}_{2}(\mathrm{dmf})\right](2)(\mathrm{dmf}=$ dimethylformamide). Complexes $\mathbf{1 - 3}$ were characterized by X-ray crystallography. Complexes $\mathbf{1}$ and $\mathbf{3}$ have distorted tetrahedral coordination environments, and complex $\mathbf{2}$ is constituted of two slightly different copper centers, both exhibiting distorted trigonal bipyramidal geometries. Complexes 1 and 2 cleave $\phi$ X174 phage DNA, both in the presence and the absence of reductant. The free ligand pbt does not show any DNA-cleaving abilities. The poor solubility of complex 3 makes it not applicable for biological tests. The occurrence of DNA breaks in the presence of various radical scavengers suggests that no diffusible radicals are involved in the DNA cleavage by complex 1 , as none of the scavengers inhibit the cleavage reaction. The DNA-cleavage products are not religated with the enzyme T4 DNA ligase, which is an additional proof that the cleavage is nonhydrolytic. Most probably the cleaving reaction involves reactive oxygen species, which could not be trapped, leading to an oxidative mechanism. An easy oxidation of $\mathrm{Cu}^{\prime \prime}(\mathrm{pbt}) \mathrm{Br}_{2}$ to $\mathrm{Cu}^{\text {III }}$ in $\mathrm{DMF}$ and the reduction of the same to $\mathrm{Cu}^{\prime}$, under similar electrochemical conditions may lead to the in situ activation of molecular oxygen, resulting in the formation of metal solvated nondiffusible radicals able to prompt the oxidative cleavage of DNA. Complex 1 and the pure ligand exhibit remarkable cytotoxic effects against the cancer cell lines L1210 and A2780 and also against the corresponding cisplatinresistant mutants of these cell lines.
\end{abstract}

\section{Introduction}

Many metal ions play an essential role in biological systems. ${ }^{1,2}$ Whereas metal ions are electron-deficient, most biological macromolecules such as proteins and DNA are electron-rich. ${ }^{3,4}$ The attraction of these opposing charges leads to a general tendency for metal ions to bind to and to interact with biopolymers. The same principle applies to the

* To whom correspondence should be addressed. Fax: +31715274671 . E-mail: reedijk@chem.leidenuniv.nl.

Leiden University.

¿niversità degli Studi di Parma.

(1) Orvig, C.; Abrams, M. J. Chem. Rev. 1999, 99, 2201-2203.

(2) Sadler, P. J. Adv. Inorg. Chem. 1991, 36, 1-48.

(3) Jamieson, E. R.; Lippard, S. J. Chem. Rev. 1999, 99, 2467-2498.

(4) Schreiber, S. L. Bioorg. Med. Chem. 1998, 6, 1127-1152. affinity of metal ions for many small molecules crucial to life, such as $\mathrm{O}_{2}$. Metals such as copper, zinc, iron, and manganese are found in metalloenzymes which facilitate a multitude of chemical reactions, including "the activation of molecular oxygen" ${ }^{5-8}$ Biomimetic model compounds of blue copper proteins, which are involved in molecular oxygen and electron transfers, have been extensively explored during the past 30 years. ${ }^{9,10}$ Various bioinspired copper complexes have also been reported as chemical nucleases in the presence

(5) Burrows, C. J.; Muller, J. G. Chem. Rev. 1998, 98, 1109-1151.

(6) Claussen, C. A.; Long, E. C. Chem. Rev. 1999, 99, 2797-2816.

(7) Cowan, J. A. Chem. Rev. 1998, 98, 1067-1087.

(8) Wolkenberg, S. E.; Boger, D. L. Chem. Rev. 2002, 102, 2477-2495.

(9) Sigman, D. S.; Mazumder, A.; Perrin, D. M. Chem. Rev. 1993, 93, $2295-2316$.

(10) Uhlmann, E.; Peyman, A. Chem. Rev. 1990, 90, 543-584.

Inorganic Chemistry, Vol. 47, No. 9, 20083719 
or absence of reducing agents, in vitro. ${ }^{11,12}$ These compounds can be explored as chemotherapeutics, such as anticancer agents, metal-mediated antibiotics, antibacterials, or antiviral drugs.

The area of optimum physiological response for the successful metal complexes, in vivo, will vary greatly depending on the element, its speciation and oxidation state, and the biochemistry of the specific compound from which it evolves (marine/natural products). Therefore, the deficiency, toxicity, and optimum physiological response of the metal drug can be dramatically modified through a combination of these variables as well as by the design of the potential ligand which may be conceived to tune the delivery of the active compound into the biological system. ${ }^{13,14}$

Since the discovery of the antitumor activity of cisplatin, cis- $\left[\mathrm{Pt}\left(\mathrm{NH}_{3}\right)_{2} \mathrm{Cl}_{2}\right]$, Pt-based combination chemotherapy is still the major treatment of solid malignancies (especially testicular, ovarian, and small-cell lung cancers). ${ }^{15,16}$ The unique DNA damage induced by Pt has not been achieved so far with any organic drugs. The platinum-biomolecule interaction is clearly critical for its antitumor activity. The serious side effects, general toxicity, and drug resistance drive inorganic chemists to develop innovative strategies for the preparation of new inorganic drugs. ${ }^{17}$ Targeted chemotherapy is a current strategy whose principal target is chromosomal DNA, especially in the case of cancerous diseases.

The design of DNA- and RNA-specific agents, capable of controlled chemical cleavage, is of paramount importance due to their potential use as DNA-targeted chemotheraupeutic drugs. ${ }^{18-20}$ Metal complexes are attractive reagents for their potential nucleolytic activity which results from their inherent diverse structural and redox properties. Some examples of such complexes include $[\mathrm{Fe}(\mathrm{edta})]^{2-}\left(\mathrm{H}_{4}\right.$ edta $=$ ethylenediamine tetraacetic acid), $\left[\mathrm{Cu}(\text { phen })_{2}\right]^{2+}$ (phen $=1,10$-phenanthroline), metalloporphyrins, Ni-azamacrocycles, $[\mathrm{Mn}(\mathrm{salen})]^{3+}(\mathrm{salen}=$ $N, N^{\prime}$-ethylenebis(salicylaldeneaminato), [Cu-desferal], [Cocyclam], $\left[\operatorname{Rh}(\text { phen })_{2}(\text { phi })\right]^{3+}$, and $\left[\operatorname{Rh}(e n)_{2}(\text { phi })\right]^{3+}\left(\mathrm{en}=N, N^{\prime}-\right.$ ethylenediamine; $\mathrm{phi}=9,10$-phenanthrenequinone dimine $)^{21-30}$ However, in most cases, the cleavage reaction must be

(11) Pitie, M.; Boldron, C.; Pratviel, G. Adv. Inorg. Chem. 2006, 58, 77130.

(12) Raja, A.; Rajendiran, V.; Maheswari, P. U.; Balamurugan, R.; Kilner, C. A.; Halcrow, M. A.; Palaniandavar, M. J. Inorg. Biochem. 2005, 99, 1717-1732.

(13) Deck, K. M.; Tseng, T. A.; Burstyn, J. N. Inorg. Chem. 2002, 41, 669-677.

(14) Liu, C. L.; Wang, M.; Zhang, T. L.; Sun, H. Z. Coord. Chem. Rev. 2004, 248, 147-168.

(15) Rosenberg, B; Vancamp, L.; Trosko, J. E.; Mansour, V. H. Nature $1969,222,385$.

(16) Wong, E.; Giandomenico, C. M. Chem. Rev. 1999, 99, 2451-2466.

(17) Chatterjee, D.; Mitra, A.; De, G. Platinum Met. Rev. 2006, 2-12.

(18) Hegg, E. L.; Burstyn, J. N. Coord. Chem. Rev. 1998, 173, 133-165.

(19) Jin, Y.; Cowan, J. A. J. Am. Chem. Soc. 2005, 127, 8408-8415.

(20) Mancin, F.; Scrimin, P.; Tecilla, P.; Tonellato, U. Chem. Commun. 2005, 2540-2548.

(21) Burrows, C. J.; Rokita, S. E. Acc. Chem. Res. 1994, 27, 295-301.

(22) Dabrowiak, J. C.; Ward, B.; Goodisman, J. Biochemistry 1989, 28, 3314-3322.

(23) Dervan, P. B. Science 1986, 232, 464-471.

(24) Joshi, R. R.; Likhite, S. M.; Kumar, R. K.; Ganesh, K. N. Biochim. Biophys. Acta 1994, 1199, 285-292.

(25) Maheswari, P. U.; Lappalainen, K.; Sfregola, M.; Barends, S.; Gamez, P.; Turpeinen, U.; Mutikainen, I.; van Wezel, G. P.; Reedijk, J. Dalton Trans. 2007, 3676-3683. initiated by an excess of an exogenous agent, such as $\mathrm{H}_{2} \mathrm{O}_{2}$, mercaptopropionic acid, dithiothreitol, or light, which limits their in vivo applications. ${ }^{31-33}$ As a result, self-activating systems that do not require an activation step are desirable. Only a few self-activating DNA-cleaving systems have been reported: (1) [Fe-BLM] (BLM= bleomycin) in the presence of molecular oxygen; (2) hydroxysalen-copper(II) (hydroxysalen $=$ bis(hydroxysalicylidene)ethylenediamine) complexes may form so-called "oxo" $\mathrm{Cu}^{\mathrm{III}}$ species spontaneously which cleave DNA; and (3) the marine natural product tambjamine $\mathrm{E}$ and the corresponding pyrrolidine derivatives induce double-strand DNA cleavage in the presence of copper(II) and molecular oxygen, without the addition of an external reducing agent. Some of the above-mentioned compounds also have a limited spectrum of antitumor properties, although the real mechanism of action inside the cells remains unclear. ${ }^{34-37}$

Recently, a copper(II)/Hpyramol complex has been reported to catalytically cleave target DNA in the absence of reductant, by the attack at multiple positions of the nucleotide. ${ }^{38}$ It has been suggested that the DNA-cleavage reaction is oxidative, through a nondiffusible radical mechanism, because radical scavengers do not significantly inhibit the DNA-cleavage reaction. The above copper complex also shows interesting cytotoxic properties in selected cancer cell lines, comparable to those achieved with the antitumor drug cisplatin. This copper complex is self-activated by the dehydrogenation of the precursor Hpyramol ligand upon coordination to the metal ion; i.e., the dehydrogenation of the ligand Hpyramol to Hpyrimol. ${ }^{39,40}$ The oxidative DNAcleavage mechanism appears to be purely ligand-based, because the redox-inactive zinc complex also shows DNAcleavage properties. $^{41}$

(26) Sitlani, A.; Long, E. C.; Pyle, A. M.; Barton, J. K. J. Am. Chem. Soc. 1992, 114, 2303-2312.

(27) Stubbe, J.; Kozarich, J. W. Chem. Rev. 1987, 87, 1107-1136.

(28) Yam, V. W. W.; Choi, S. W. K.; Lo, K. K. W.; Dung, W. F.; Kong, R. Y. C. J. Chem. Soc., Chem. Commun. 1994, 2379-2380.

(29) Yazlovitskaya, E. M.; DeHaan, R. D.; Persons, D. L. Biochem. Biophys. Res. Commun. 2001, 283, 732-737.

(30) Gravert, D. J.; Griffin, J. H. Inorg. Chem. 1996, 35, 4837-4847.

(31) Kirin, S. I.; Happel, C. M.; Hrubanova, S.; Weyhermuller, T.; Klein, C.; Metzler-Nolte, N. Dalton Trans. 2004, 1201-1207.

(32) Pogozelski, W. K.; Tullius, T. D. Chem. Rev. 1998, 98, 1089-1107.

(33) Sigman, D. S.; Bruice, T. W.; Mazumder, A.; Sutton, C. L. Acc. Chem. Res. 1993, 26, 98-104.

(34) Burger, R. M. Chem. Rev. 1998, 98, 1153-1169.

(35) Lamour, E.; Routier, S.; Bernier, J. L.; Catteau, J. P.; Bailly, C.; Vezin, H. J. Am. Chem. Soc. 1999, 121, 1862-1869.

(36) Melvin, M. S.; Tomlinson, J. T.; Saluta, G. R.; Kucera, G. L.; Lindquist, N.; Manderville, R. A. J. Am. Chem. Soc. 2000, 122, 63336334.

(37) Melvin, M. S.; Wooton, K. E.; Rich, C. C.; Saluta, G. R.; Kucera, G. L.; Lindquist, N.; Manderville, R. A. J. Inorg. Biochem. 2001, 87, $129-135$.

(38) Maheswari, P. U.; Roy, S.; den Dulk, H.; Barends, S.; van Wezel, G.; Kozlevcar, B.; Gamez, P.; Reedijk, J. J. Am. Chem. Soc. 2006, 128, $710-711$.

(39) de Hoog, P.; Pachon, L. D.; Gamez, P.; Lutz, M.; Spek, A. L.; Reedijk, J. Dalton Trans. 2004, 2614-2615.

(40) Pachon, L. D.; Golobic, A.; Kozlevcar, B.; Gamez, P.; Kooijman, H.; Spek, A. L.; Reedijk, J. Inorg. Chim. Acta 2004, 357, 3697-3702.

(41) Maheswari, P. U.; Barends, S.; Ozalp-Yaman, S.; de Hoog, P.; Casellas, H.; Teat, S. J.; Massera, C.; Lutz, M.; Spek, A. L.; van Wezel, G. P.; Gamez, P.; Reedijk, J. Chem.-Eur. J. 2007, 13, 5213-5222. 
Scheme 1. The Ligand 2-(2-Pyridyl)benzthiazole (pbt) was Prepared in One Step by the Condensation of 2-Aminobenzenethiol and Pyridine Carboxyaldehyde

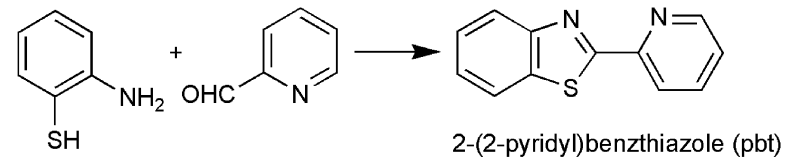

Scheme 2. Possible Mechanism of Action

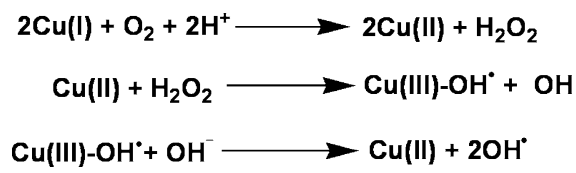

In the present paper, the synthesis and the characterization of two new copper complexes and a zinc complex, namely, $\left[\mathrm{Cu}(\mathrm{pbt}) \mathrm{Br}_{2}\right](\mathbf{1}),\left[\mathrm{Cu}(\mathrm{pbt}) \mathrm{Br}_{2}(\mathrm{dmf})\right]_{2}(\mathbf{2})$, and $\left[\mathrm{Zn}(\mathrm{pbt}) \mathrm{Cl}_{2}\right]$ (3) $(\mathrm{pbt}=$ 2-(2-pyridyl)benzthiazole; $\mathrm{dmf}=$ dimethylformamide), are reported. The DNA cleavage and the cytotoxic properties of $\mathbf{1}$ and the free pbt ligand are discussed. Because complex 3 exhibits limited solubility in the common solvents used for biological assays, its potential activity toward DNA cleavage and anticancer activity could not be evaluated.

Description of the Structures. $\left[\mathrm{Cu}(\mathrm{pbt}) \mathrm{Br}_{2}\right](\mathbf{1})$. Reaction of copper(II) bromide with the ligand pbt (Scheme 1) in acetonitrile yields dark-red prismatic crystals of $\mathbf{1}$ after one day. Compound $\mathbf{1}$ crystallizes in the triclinic space group $P \overline{1}$. An ORTEP perspective view of $\mathbf{1}$ is depicted in Figure 1. Selected bond lengths and angles are given in Table 1, and details for the structure solution and refinement are summarized in Table 2. The $\mathrm{Cu}^{\mathrm{II}}$ ion is in a distorted tetrahedral coordination environment formed by one pbt ligand and two bromide anions (Figure 1). The $\mathrm{Cu}-\mathrm{N}$ and the $\mathrm{Cu}-\mathrm{Br}$ bond distances are in normal ranges for such coordination geometry. ${ }^{42}$ The coordination angles reflect the strong distortion which is most likely the result of the small bite angle of the pbt ligand. ${ }^{43,44}$ Space-filling models clearly show that bulky bromide anions cannot make the geometry more "planar", so an intermediate geometry is the result. The crystal packing of $\mathbf{1}$ (see Figure S1, Supporting Information) reveals the occurrence of $\pi-\pi$ interactions between pairs of copper complexes.

The polycrystalline electron paramagnetic resonance (EPR) spectra of complex 1 both at room temperature (RT) and 70 $\mathrm{K}$ exhibits an unresolved axial signal $\left(g_{\|}>g_{\perp}>2.0\right)$ with $g_{\|}=2.24$ and $g_{\perp}=2.08$ which would suggest a $\mathrm{d}_{x^{2}-y^{2}}$ ground state. The absence of hyperfine splitting and the high $g_{\|}$value indicates a broadening due to the fact that the $\mathrm{Cu}$ (II) atoms are too close in the lattice. The frozen solution spectrum in DMF exhibits a broad rather isotropic spectrum centered around $g=2.11$, with unresolved hyperfine splitting.

(42) Murray, H. H.; Raptis, R. G.; Fackler, J. P. Inorg. Chem. 1988, 27, 26-33.

(43) Atria, A. M.; Baggio, R. F.; Espinosa, N.; Garland, M. T.; Manzur, J.; Moreno, Y.; Spodine, E. Acta Crystallogr., Sect. C 1994, 50, 10661069.

(44) Riggio, I.; van Albada, G. A.; Ellis, D. D.; Mutikainen, I.; Spek, A. L.; Turpeinen, U.; Reedijk, J. Polyhedron 2001, 20, 2659-2666.

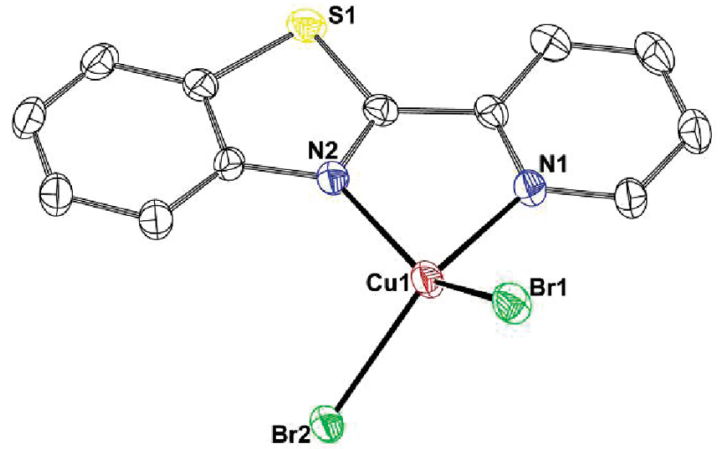

Figure 1. ORTEP drawing (30\% probability level) of $\left[\mathrm{Cu}(\mathrm{pbt}) \mathrm{Br}_{2}\right]$ (1). Hydrogen atoms are omitted for clarity.

Table 1. Selected Bond Lengths (A) and Angles (deg) for 1-3

\begin{tabular}{|c|c|c|c|}
\hline \multicolumn{4}{|c|}{ Compound 1} \\
\hline $\mathrm{Cu} 1-\mathrm{Br} 1$ & $2.352(1)$ & $\mathrm{Cu} 1-\mathrm{Br} 2$ & $2.348(1)$ \\
\hline $\mathrm{Cu} 1-\mathrm{N} 1$ & $2.011(3)$ & $\mathrm{Cu} 1-\mathrm{N} 2$ & $2.022(3)$ \\
\hline $\mathrm{Br} 1-\mathrm{Cu} 1-\mathrm{Br} 2$ & $103.2(1)$ & $\mathrm{Br} 1-\mathrm{Cu} 1-\mathrm{N} 1$ & $97.1(1)$ \\
\hline $\mathrm{Br} 1-\mathrm{Cu} 1-\mathrm{N} 2$ & $137.9(1)$ & $\mathrm{Br} 2-\mathrm{Cu} 1-\mathrm{N} 1$ & $147.8(1)$ \\
\hline $\mathrm{Br} 2-\mathrm{Cu} 1-\mathrm{N} 2$ & $99.3(1)$ & $\mathrm{N} 1-\mathrm{Cu} 1-\mathrm{N} 2$ & $81.2(1)$ \\
\hline \multicolumn{4}{|c|}{ Compound $2^{a}$} \\
\hline $\mathrm{Cu} 1 \mathrm{a}-\mathrm{Br} 1 \mathrm{a}$ & $2.529(1)$ & $\mathrm{Cu} 1 \mathrm{a}-\mathrm{Br} 2 \mathrm{a}$ & $2.448(1)$ \\
\hline $\mathrm{Cu} 1 \mathrm{a}-\mathrm{N} 1 \mathrm{a}$ & $2.126(4)$ & $\mathrm{Cu} 1 \mathrm{a}-\mathrm{N} 2 \mathrm{a}$ & $2.009(4)$ \\
\hline $\mathrm{Cu} 1 \mathrm{a}-\mathrm{O} 1 \mathrm{a}$ & $1.964(4)$ & & \\
\hline $\mathrm{Cu} 1 \mathrm{~b}-\mathrm{Br} 1 \mathrm{~b}$ & $2.493(1)$ & $\mathrm{Cu} 1 \mathrm{~b}-\mathrm{Br} 2 \mathrm{~b}$ & $2.453(1)$ \\
\hline $\mathrm{Cu} 1 \mathrm{~b}-\mathrm{N} 1 \mathrm{~b}$ & $2.031(5)$ & $\mathrm{Cu} 1 \mathrm{~b}-\mathrm{N} 2 \mathrm{~b}$ & $2.154(4)$ \\
\hline $\mathrm{Cu} 1 \mathrm{~b}-\mathrm{O} 1 \mathrm{~b}$ & $1.965(5)$ & & \\
\hline $\mathrm{Br} 1 \mathrm{a}-\mathrm{Cu} 1 \mathrm{a}-\mathrm{Br} 2 \mathrm{a}$ & $116.6(1)$ & $\mathrm{Br} 2 \mathrm{a}-\mathrm{Cu} 1 \mathrm{a}-\mathrm{N} 1 \mathrm{a}$ & $128.9(1)$ \\
\hline $\mathrm{N} 1 \mathrm{a}-\mathrm{Cu} 1 \mathrm{a}-\mathrm{Br} 1 \mathrm{a}$ & $114.3(1)$ & $\mathrm{N} 2 \mathrm{a}-\mathrm{Cu} 1 \mathrm{a}-\mathrm{O} 1 \mathrm{a}$ & $167.1(2)$ \\
\hline $\mathrm{Br} 1 \mathrm{~b}-\mathrm{Cu} 1 \mathrm{~b}-\mathrm{Br} 2 \mathrm{~b}$ & $117.7(1)$ & $\mathrm{Br} 2 \mathrm{~b}-\mathrm{Cu} 1 \mathrm{~b}-\mathrm{N} 2 \mathrm{~b}$ & $135.0(1)$ \\
\hline $\mathrm{N} 2 \mathrm{~b}-\mathrm{Cu} 1 \mathrm{~b}-\mathrm{Br} 1 \mathrm{~b}$ & $106.4(1)$ & $\mathrm{N} 1 \mathrm{~b}-\mathrm{Cu} 1 \mathrm{~b}-\mathrm{O} 1 \mathrm{~b}$ & $169.6(2)$ \\
\hline \multicolumn{4}{|c|}{ Compound $\mathbf{3}$} \\
\hline $\mathrm{Zn} 1-\mathrm{Cl1}$ & $2.206(1)$ & $\mathrm{Zn} 1-\mathrm{Cl} 2$ & $2.183(1)$ \\
\hline $\mathrm{Zn} 1-\mathrm{N} 1$ & $2.101(2)$ & $\mathrm{Zn} 1-\mathrm{N} 2$ & $2.060(2)$ \\
\hline $\mathrm{Cl} 1-\mathrm{Zn} 1-\mathrm{Cl} 2$ & $119.8(1)$ & $\mathrm{C} 11-\mathrm{Zn} 1-\mathrm{N} 1$ & $116.1(1)$ \\
\hline $\mathrm{C} 11-\mathrm{Zn} 1-\mathrm{N} 2$ & $110.6(1)$ & $\mathrm{C} 12-\mathrm{Zn} 1-\mathrm{N} 1$ & $110.9(1)$ \\
\hline $\mathrm{Cl} 2-\mathrm{Zn} 1-\mathrm{N} 2$ & $112.9(1)$ & $\mathrm{N} 1-\mathrm{Zn} 1-\mathrm{N} 2$ & $79.9(1)$ \\
\hline
\end{tabular}

Probably on dissolution some bromide ions may dissociate, giving more than one species, which in combination with a poor glass do not show resolution.

$\left[\mathbf{C u}(\mathbf{p b t}) \mathrm{Br}_{2}(\mathbf{d m f})\right]$ (2). The reaction of copper(II) bromide with pbt in DMF leads to the formation of green prismatic crystals of $\mathbf{2}$ after 7 days. Compound $\mathbf{2}$ crystallizes in the triclinic space group $P \overline{1}$. An ORTEP perspective view of $\mathbf{2}$ is depicted in Figure 2. Selected bond lengths and angles are given in Table 1, and crystal data are shown in Table 2. The asymmetric unit of this compound consists of two slightly different copper(II) ions identified as $\mathrm{Cu} 1 \mathrm{a}$ and $\mathrm{Cu} 1 \mathrm{~b}$ (Figure 2). Both copper centers are in distorted trigonal bipyramidal environments $\left(\tau_{5}=0.64\right.$ for $\mathrm{Cu} 1 \mathrm{a}$, and $\tau_{5}=$ 0.58 for $\mathrm{Cu} 1 \mathrm{~b}),{ }^{45}$ with $\mathrm{N}_{2} \mathrm{Br}_{2} \mathrm{O}$ donor sets. In both cases, the $\mathrm{Cu}-\mathrm{N}$ and $\mathrm{Cu}-\mathrm{Br}$ bond lengths can be considered as normal. ${ }^{46}$ The $\mathrm{Cu}-\mathrm{O}_{\mathrm{dmf}}$ distance is also at a typical range. ${ }^{47}$

(45) Addison, A. W.; Rao, T. N.; Reedijk, J.; van Rijn, J.; Verschoor, G. C. J. Chem. Soc., Dalton Trans. 1984, 1349-1356.

(46) Willett, R. D.; Pon, G.; Nagy, C. Inorg. Chem. 2001, 40, 4342-4352.

(47) Pardo, O.; Tomas, A.; Mazurier, A.; Nguyen-Huy, D.; Viossat, B. Z. Kristallogr. New Cryst. Struct. 2000, 215, 111-112. 
Table 2. Crystal Data and Structure Refinement for Coordination Compounds 1-3

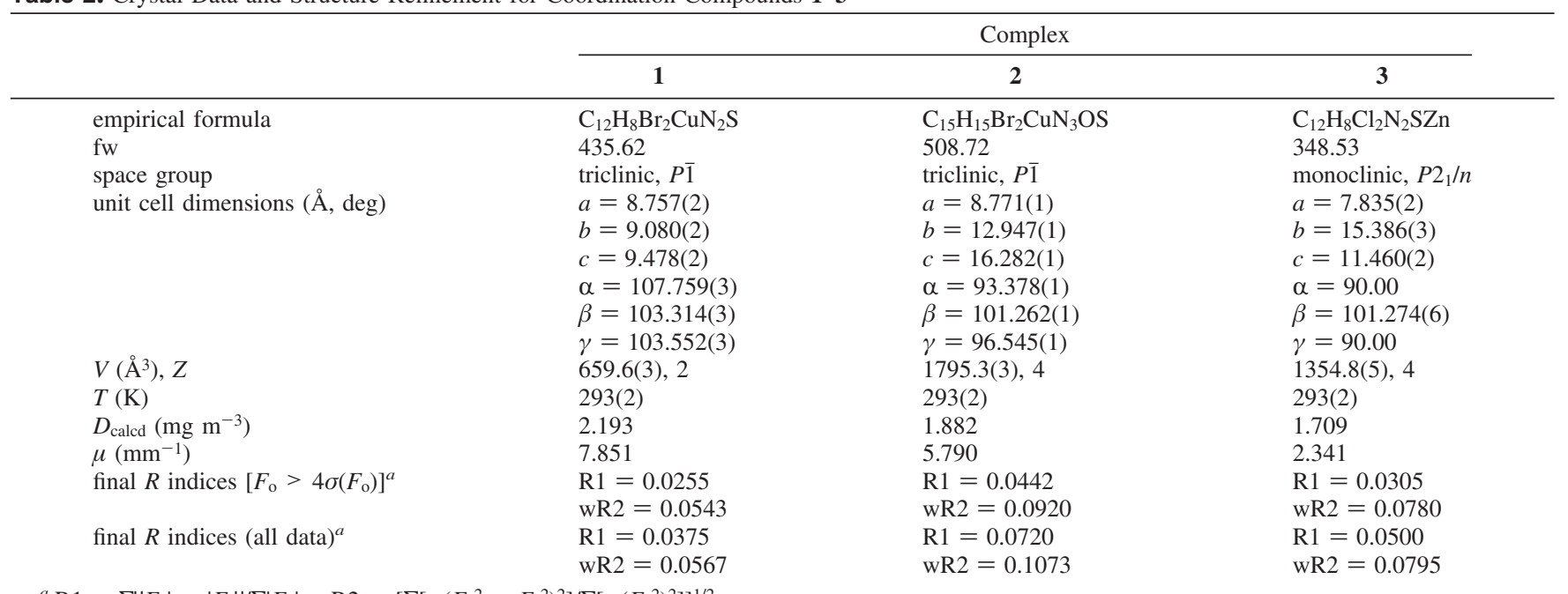$$
{ }^{a} \mathrm{R} 1=\Sigma|| F_{\mathrm{o}}|-| F_{\mathrm{c}}|/ \Sigma| F_{\mathrm{o}} \mid, w \mathrm{R} 2=\left[\Sigma\left[w\left(F_{\mathrm{o}}{ }^{2}-F_{\mathrm{c}}{ }^{2}\right)^{2}\right] / \Sigma\left[w\left(F_{\mathrm{o}}{ }^{2}\right)^{2}\right]\right]^{1 / 2} .
$$

The coordination environments of $\mathrm{Cu} 1 \mathrm{a}$ and $\mathrm{Cu} 1 \mathrm{~b}$ differ by the spatial arrangement of the pbt ligand. Indeed, for $\mathrm{Cu} 1 \mathrm{a}$, the axial positions of the trigonal bipyramid are occupied by the benzothiazole nitrogen atom $\mathrm{N} 2 \mathrm{a}$ and the DMF oxygen atom O1a. For $\mathrm{Cu} 1 \mathrm{~b}$, it is the pyridine nitrogen atom N1b which is occupying one of the axial positions, the other axial ligand still being DMF (Figure 2). It thus appears that the ligands are in inverted orientations. The presence of coordinated DMF molecules does not allow $\pi-\pi$ contacts between the complexes (all contact distances are greater than $3.6 \AA$ ), in contrast to $\mathbf{1}$, probably owing to the steric

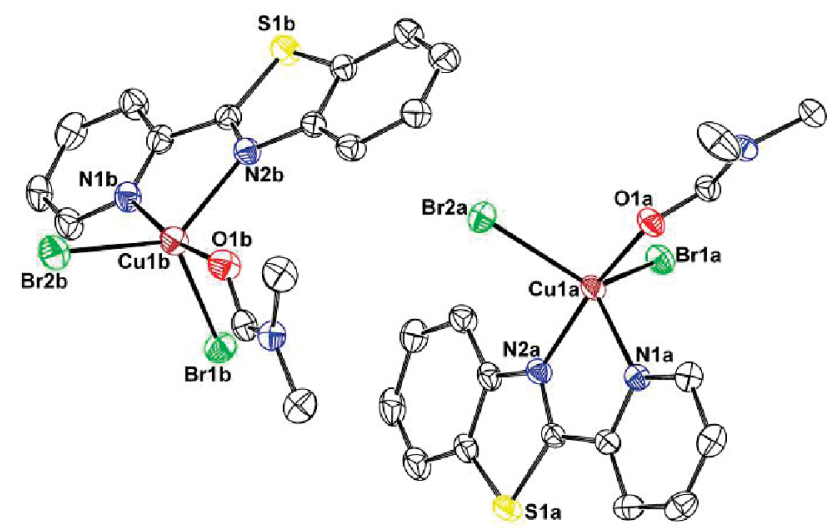

Figure 2. ORTEP drawing (30\% probability level) of the two slightly different $\left[\mathrm{Cu}(\mathrm{pbt}) \mathrm{Br}_{2}(\mathrm{dmf})\right]$ molecules (2). Hydrogen atoms are omitted for clarity.

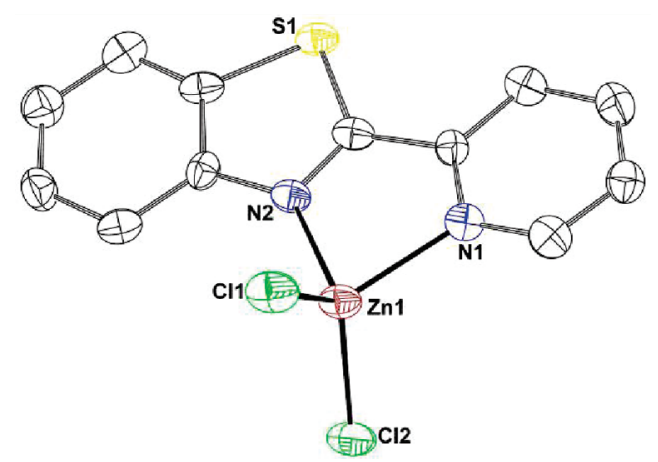

Figure 3. ORTEP drawing (30\% probability level) of $\left[\mathrm{Zn}(\mathrm{pbt}) \mathrm{Cl}_{2}\right](\mathbf{3})$. Hydrogen atoms are omitted for clarity. hindrance of the methyl groups (see Figure S2, Supporting Information).

$\left[\mathbf{Z n}(\mathbf{p b t}) \mathbf{C l}_{2}\right]$ (3). The reaction of zinc(II) chloride with pbt in acetonitrile produces prismatic colorless crystals of $\mathbf{3}$ after two days. Compound $\mathbf{3}$ crystallizes in the monoclinic $P 2_{1} / n$ space group. The important bond parameters and crystallographic data for the structural analysis are listed in Tables 1 and 2, respectively. An ORTEP perspective view of $\mathbf{3}$ is depicted in Figure 3. The coordination geometry of $\mathbf{3}$ is comparable to the one of $\mathbf{1}$. The zinc(II) ion is in a distorted tetrahedral environment formed by two chloride anions and one pbt ligand (Figure 3). The $\mathrm{Zn}-\mathrm{N}$ as well as the $\mathrm{Zn}-\mathrm{Cl}$ bond distances are in normal ranges. ${ }^{48}$ The coordination angles reflect the distortion due to the small bite angle of the ligand pbt, with the N1-Zn1-N2 angle amounting to $79.9(1)^{\circ}{ }^{49}$ Similarly to 1 , the crystal packing of $\mathbf{3}$ shows $\pi-\pi$ interactions between zinc(II) complexes (see Figure S3, Supporting Information).

DNA-Cleavage Properties of Complex 1. The DNAcleaving abilities of complex $\mathbf{1}$ were investigated using $\phi \mathrm{X} 174$ phage DNA in the absence and in the presence of reductant (ascorbic acid). The complex was dissolved in DMF to prepare a $2 \mathrm{mM}$ stock solution which was diluted to the appropriate concentration needed for a specific study with a phosphate buffer. DMF solution of the free ligand or free $\mathrm{CuBr}_{2}$ in phosphate buffer does not cleave DNA. The sole use of buffer (i.e., without complex or free ligand) containing $2 \%$ of DMF does not lead to the alteration of $\phi \mathrm{X} 174$ phage DNA. The reactions of $1-5 \mu \mathrm{M}$ solutions of complex 1 with a $20 \mu \mathrm{M}$ solution (in base pairs) of $\phi \mathrm{X} 174$ phage DNA (supercoiled, covalently coiled coil (CCC)), in the presence of $10 \mu \mathrm{M}$ ascorbic acid in a phosphate buffer, lead to the cleavage of supercoiled DNA to open circular (OC) and to the linear form, after an incubation time of $2 \mathrm{~h}$ at $37^{\circ} \mathrm{C}$ (Figure 4). Comparative reactions have been carried out in the presence of various radical inhibitors and/or

(48) Pang, J.; Marcotte, E. J. P.; Seward, C.; Brown, R. S.; Wang, S. N. Angew. Chem., Int. Ed. 2001, 40, 4042-4045.

(49) Alexiou, M.; Dendrinou-Samara, C.; Raptopoulou, C. P.; Terzis, A.; Kessissoglou, D. P. Inorg. Chem. 2002, 41, 4732-4738. 


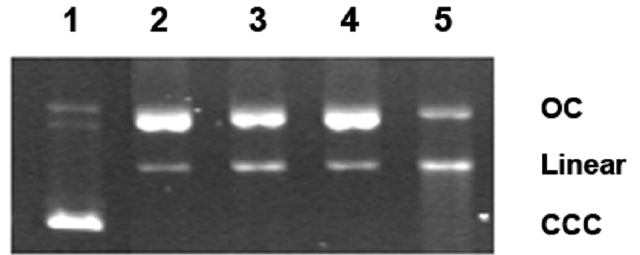

Figure 4. Agarose gel electrophoresis of the cleavage reaction $(2 \mathrm{~h})$ of $\phi \mathrm{X} 174$ supercoiled phage DNA $(20 \mu \mathrm{M})$ mediated by the copper complex 1 at varying concentrations $(1-5 \mu \mathrm{M})$ in the presence of ascorbic acid, at $37^{\circ} \mathrm{C}$, in a phosphate buffer at $\mathrm{pH} 7.2$ (Lanes 2 to 5). Lane 1: pure DNA (20 $\mu \mathrm{M}$ in base pairs) without any additives. Abbreviations: the supercoiled DNA migrates fastest and is indicated by "CCC" (covalently coiled coil), the nicked or relaxed form of the DNA migrates slowest and is referred to as "OC"(open circle), and the linear form, where present, migrates with an intermediate rate.

trappers such as $\mathrm{NaN}_{3}$, superoxide dismutase, DMSO, and ethanol. The cleavage is inhibited by superoxide dismutase, DMSO, and under an argon atmosphere (Figure 5), suggesting a catalytic hydroxyl-type radical mechanism in the presence of reductant and molecular oxygen. The cleavage is not inhibited in the presence of an excess of $\mathrm{NaCl}, \mathrm{NaN}_{3}$, or distamycin and if the reaction is performed in the dark (Figure 5). An excess over the stoichiometric amounts of complex 1 (complex concentrations ranging from 5 to 220 $\mu \mathrm{M})$ also appears capable of cleaving $\phi X 174$ phage DNA without any added reductant after an incubation time of $2 \mathrm{~h}$ at $37{ }^{\circ} \mathrm{C}$ (Figure 6). The cleavage efficiency depends both on the complex concentration and on the incubation periods. The cleavage mediated by complex $\mathbf{1}$ does not produce any double-strand cleavage on the DNA. This is clearly evidenced in Figure 6, where the linear form only appears after the supercoiled (CCC) form has been completely converted to the OC form.

When the cleavage experiments are performed in the presence of various radical inhibitors (as indicated above), no retardation in the DNA-cleavage reaction is observed with any of these additives in the absence of any added reductant (Figure 7). After reaction with complex 1, the $\phi$ X174 phage DNA-cleavage products could not be religated by the T4 DNA ligase under the conditions described in the Experimental Section, whereas the PstI enzyme digested $\phi \mathrm{X} 174$ DNA can be very efficiently $(>99 \%)$ religated (data not shown).

These results are indicative of an oxidative-type cleavage of DNA rather than a hydrolytic one. When analogous cleavage experiments are performed with other metal salts such as $\mathrm{MnCl}_{2}, \mathrm{FeCl}_{2}, \mathrm{NiCl}_{2}, \mathrm{CoCl}_{2}$, and $\mathrm{CuCl}_{2}$, in the presence of stoichiometric amounts of ligand pbt (1:1), only $\mathrm{CuCl}_{2}$ mediates DNA breaks (without any reductant), producing the OC form in an oxidative manner (Figure 8).

As illustrated in Figure 9, complex 1 follows pseudo-firstorder kinetics (single exponential curve). The highest rate constant of $2.24 \mathrm{~h}^{-1}$ is observed at a concentration of 20 $\mu \mathrm{M}$, under pseudo-Michaelis-Menten conditions. For pseudoMichaelis-Menten treatment, the equation ${ }^{50}$ below is used to determine $k_{\mathrm{obs}}$ from

$$
y=\left(y_{0}-\text { const }\right) \exp \left(-k_{\text {obs }} x\right)+\text { const }
$$

where $y_{0}$ is the initial percentage of a specific form of DNA, $y$ is the percentage of a specific form of DNA at the time $x$, const is the percentage of uncleaved DNA, and $k_{\text {obs }}$ is the apparent rate constant (Figure 10). True Michaelis-Menten conditions could not be applied, because the present system is not catalytic and single in turnover.

Cytotoxic Studies in Cancer Cell Lines. Cytotoxicity properties of complex 2, the ligand pbt, and cisplatin, under similar conditions, have been evaluated on L1210 murine leukemia cancer cell lines, which are sensitive (L1210) and resistant (L1210-R) to cisplatin, and on A2780 human ovarian carcinoma cell lines, which are sensitive (A2780) and resistant (A2780-R) to cisplatin (Table 3). The $\mathrm{IC}_{50}($ in $\mu \mathrm{M}$ ) values for the cell lines $\mathrm{L} 1210$ and A2780 upon treatment with complex 2 are slightly higher than those obtained with cisplatin. For the resistant L1210-R and A2780-R cancer cell lines (i.e., known to be resistant to cisplatin), complex $\mathbf{2}$ is more active than cisplatin (Table 3).

These positive results are interesting for potential applications, because the activity of this labile copper complex is comparable to the one of the platinum drug. In addition, the copper complex overcomes the cross-resistance observed for cisplatin in both resistant cancer cell lines. Indeed, the resistance factors (RF), ${ }^{51}$ are lower for the copper complex compared with those of cisplatin. ${ }^{52}$ The cytotoxic results for the free ligand are unexpected. Actually, the $\mathrm{IC}_{50}$ values achieved with free pbt are in the range of those of cisplatin for the sensitive cell lines and lower for the resistance cell lines. It has to be mentioned that if the experimental conditions used with complex $\mathbf{2}$ are applied to the free ligand, the latter does not cleave $\phi X 174$ phage DNA via a "selfactivation" mechanism. This activity of the free ligand thus suggests that its in vivo mechanism of action is more complicated than the one occurring for the in vitro DNA cleavage. The activity of the ligand can be due to enhanced tumor cell uptake and other inhibitory reactions such as protein binding inside the cancer cells leading to apoptosis.

Cyclic Voltammetry (CV). Cu(pbt)Br $\mathrm{B}_{2}(\mathbf{1})$ has a distorted tetrahedral geometry and exhibits an easy one-electron reduction (R1, Figure 11A) at $-0.24 \mathrm{~V}$ vs $\mathrm{Ag} / \mathrm{AgCl}$. This reduction is relatively more facile compared with that of other, related complexes. ${ }^{53-55}$ Under the same conditions, the corresponding oxidation of $\mathrm{Cu}^{\mathrm{I}}$ to $\mathrm{Cu}^{\mathrm{II}}(\mathrm{O} 1$, Figure 11A) is less reversible $\left(\Delta E_{\mathrm{p}}=150 \mathrm{mV}, 60 \mathrm{mV}\right.$ for a Nernstian one-electron redox system), reflecting a potential structural deformation of the $\mathrm{Cu}^{\mathrm{I}}$ state in the presence of DMF.

(50) Sreedhara, A.; Freed, J. D.; Cowan, J. A. J. Am. Chem. Soc. 2000, $122,8814-8824$.

(51) Komeda, S.; Lutz, M.; Spek, A. L.; Chikuma, M.; Reedijk, J. Inorg. Chem. 2000, 39, 4230-4236.

(52) Komeda, S.; Lutz, M.; Spek, A. L.; Yamanaka, Y.; Sato, T.; Chikuma, M.; Reedijk, J. J. Am. Chem. Soc. 2002, 124, 4738-4746.

(53) Addison, A. W.; Rao, T. N.; Sinn, E. Inorg. Chem. 1984, 23, 19571967.

(54) Karagiannidis, P.; Aslanidis, P.; Kessissoglou, D. P.; Krebs, B.; Dartmann, M. Inorg. Chim. Acta 1989, 156, 47-56.

(55) Palaniandavar, M.; Sujatha, M. Transition Met. Chem. 1994, 19, 439 . 


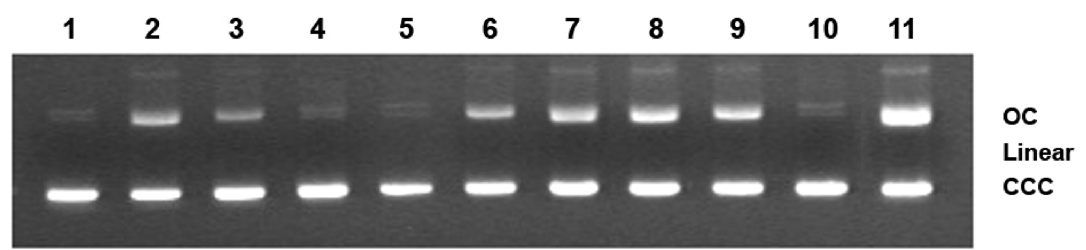

Figure 5. Agarose gel electrophoresis of the oxidative cleavage reaction of $\phi \mathrm{X} 174$ supercoiled phage DNA (20 $\mu \mathrm{M}$ DNA) with copper complex 1 (0.5 $\mu \mathrm{M})$ in the presence of ascorbic acid $(10 \mu \mathrm{M})$, lane 11 , and in the presence of various additives + ascorbic acid (lanes $2-10$ ), for $2 \mathrm{~h}$ at $37{ }^{\circ} \mathrm{C}$ in a phosphate buffer at $\mathrm{pH}$ 7.2. Lane 1, pure DNA, without any additives (20 $\mu \mathrm{M}$ in base pairs); lane $2,+100 \mu \mathrm{M} \mathrm{NaN}$; Lane 3 , + superoxide dismutase, 0.5 unit; lane 4, + DMSO; lane 5, reaction under argon; lane 6, + distamycin $100 \mu \mathrm{M}$; lane 7, + ethanol; lane 8, reaction in dark; lane 9, +350 $\mu \mathrm{M} \mathrm{NaCl}$; lane $10,+$ $10 \mu \mathrm{M}$ ascorbic acid (without complex 1). For abbreviations key, see Figure 4.

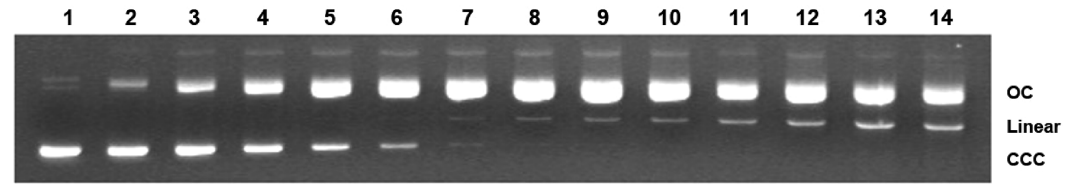

Figure 6. Agarose gel electrophoresis of the oxidative cleavage of supercoiled DNA ( $20 \mu \mathrm{M}$ in base pairs) in the absence (lane 1) and in the presence of copper complex 1 at various concentrations for $2 \mathrm{~h}$ at $37{ }^{\circ} \mathrm{C}$ in a phosphate buffer at pH 7.2 (lanes $2-14=5-220 \mu \mathrm{M}$, in increasing order, respectively). For abreviations key, see Figure 4. No evidence for a direct double-strand cleavage is observed. The cleavage of supercoiled DNA to OC and then to linear form occurs in a stepwise manner.

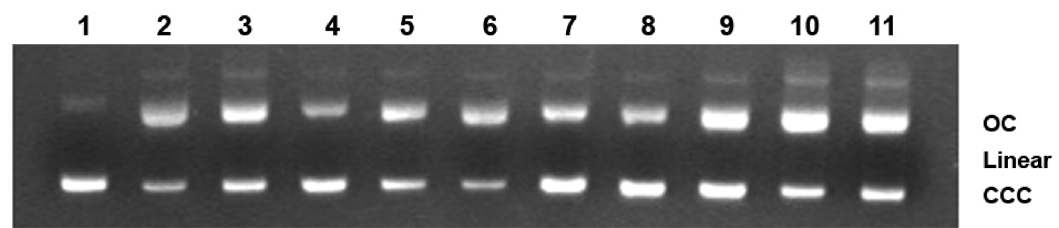

Figure 7. Agarose gel electrophoresis of the oxidative cleavage reaction of $\phi \mathrm{X} 174$ supercoiled phage DNA ( $20 \mu \mathrm{M}$ in base pairs) with the copper complex $1(40 \mu \mathrm{M})$ without reductant (lane 11) and in the presence of various additives (lanes 1-10), for $2 \mathrm{~h}$ at $37^{\circ} \mathrm{C}$ in a phosphate buffer at $\mathrm{pH} 7.2$. Lane 1 , pure DNA, without any additives ( $20 \mu \mathrm{M}$ in base pairs); lane $2,+100 \mu \mathrm{M} \mathrm{NaN}_{3}$; lane 3, + superoxide dismutase, 0.5 unit; lane 4 , + DMSO; lane 5, + ethanol; lane 6, + distamycin $100 \mu \mathrm{M}$; lane 7, $+\mathrm{D}_{2} \mathrm{O}$; lane 8, $350 \mu \mathrm{M} \mathrm{NaCl}$; lane 9, reaction under argon; lane 10, reaction in the dark. For abbreviations key, see Figure 4.

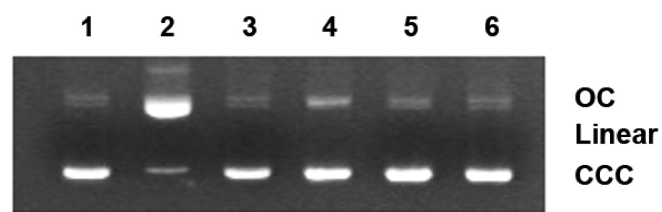

Figure 8. Agarose gel electrophoresis of the oxidative cleavage reaction of the phage DNA ( $20 \mu \mathrm{M}$ in base pairs) with $50 \mu \mathrm{M}$ of free ligand pbt and with different metal salts, without reductant, for $2 \mathrm{~h}$ at $37{ }^{\circ} \mathrm{C}$ in a phosphate buffer at $\mathrm{pH}$ 7.2. Lane 1, pure DNA, without any additives; lane $2,+50 \mu \mathrm{M}$ of $\mathrm{CuCl}_{2} \cdot 2 \mathrm{H}_{2} \mathrm{O}$; lane $3,+50 \mu \mathrm{M}$ of $\mathrm{MnCl}_{2} ;$ lane $4,+50 \mu \mathrm{M}$ of $\mathrm{FeCl}_{2}$; lane $5,+50 \mu \mathrm{M}$ of $\mathrm{CoCl}_{2}$; lane $6,+50 \mu \mathrm{M}$ of $\mathrm{NiCl}_{2}$. For abbreviations key, see Figure 4.

Actually, isolated crystals of $\left[\mathrm{Cu}(\mathrm{pbt}) \mathrm{Br}_{2}(\mathrm{dmf})\right]$ from $\mathrm{DMF}$ show a coordination geometry change from a tetrahedron to a distorted trigonal bipyramid. The multiple scan cycles confirm the preservation of the chemical composition (from the starting compound).

During the anodic scan, two consecutive oxidation waves are observed (O2 and $\mathrm{O} 3$, Figure 11B), which are ascribed to the $\mathrm{Cu}^{\mathrm{II}} / \mathrm{Cu}^{\mathrm{III}}$ couple and to the ligand oxidation (with reference to ferrocene). The one-electron reduction wave (R2, Figure 11B) observed during the reverse scan is assigned to the $\mathrm{Cu}^{\mathrm{III}} \rightarrow \mathrm{Cu}^{\mathrm{II}}$ reduction which is quasi reversible $\left(\Delta E_{\mathrm{p}}=\right.$ $130 \mathrm{mV}$ ) in nature. The ligand oxidation appears to be completely irreversible with a non-Nernstian behavior (as anodic and cathodic shifts are observed upon increase in the scan rate), which can be ascribed to a heterogeneous electron transfer coupled to a chemical reaction. ${ }^{56}$ Under the potential window up to $1.5 \mathrm{~V}$, these ligand oxidations also affect the $\mathrm{Cu}^{\mathrm{III}} / \mathrm{Cu}^{\mathrm{II}}$ redox cycle on multiple scans. The facile oxidation

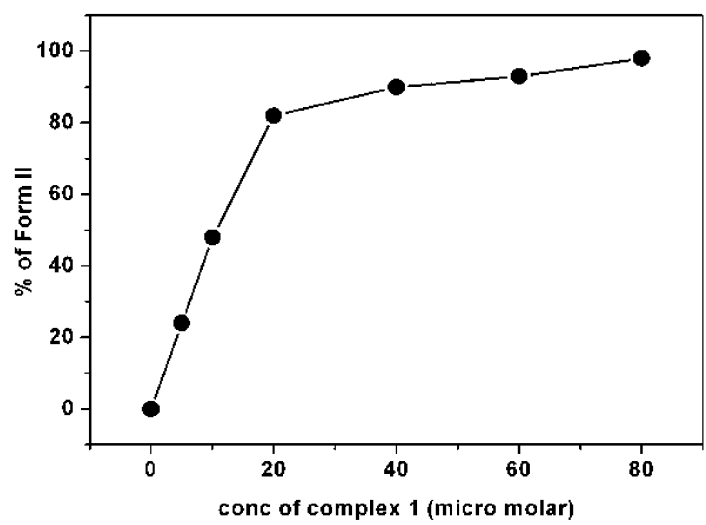

Figure 9. Plot of the different concentrations of complex 1 (used to digest $\phi \mathrm{X} 174$ phage DNA $(20 \mu \mathrm{M}))$ versus the percentage of OC form which is formed after $2 \mathrm{~h}$ incubation at $37^{\circ} \mathrm{C}$ at $\mathrm{pH}$ 7.2.

to $\mathrm{Cu}^{\mathrm{III}}$ around $0.5 \mathrm{~V}$ with respect to $\mathrm{Ag} / \mathrm{AgCl}$ reference and the quasi-reversible reduction to $\mathrm{Cu}^{\mathrm{II}}$ are important aspects for the self-activation toward DNA cleavage as depicted in Scheme 2.

\section{Discussion}

The metal-ion-dependent oxidative DNA cleavage by $\mathrm{Cu}^{\mathrm{II}}$ complexes is of topical interest (Scheme 2). In the presence of suitable chelating ligands, the $\mathrm{d}^{9}$ electronic state of $\mathrm{Cu}^{\mathrm{II}}$ may easily accept an electron (from the solvent environment, or any electron diffusing systems) to produce stable $\mathrm{d}^{10} \mathrm{Cu}^{\mathrm{I}}$ species. $^{5,11}$ Such redox-active systems may achieve the decomposition of $\mathrm{H}_{2} \mathrm{O}_{2}$ to reactive oxygen species (through 


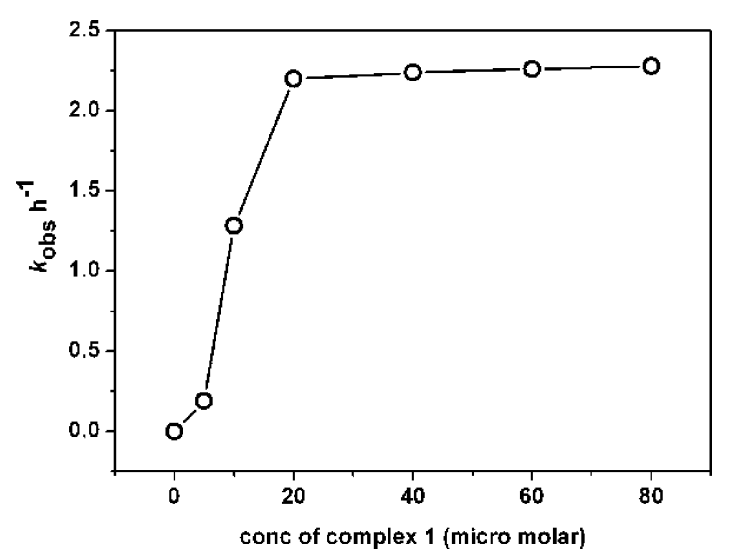

Figure 10. Plot showing the saturation kinetics for the cleavage of $\phi \mathrm{X} 174$ phage DNA using different concentrations of complex $\mathbf{1}$.

a superficial Fenton mechanism), which can oxidize DNA by multiple attacks at the sugars and nucleobases. The coordination geometry around the $\mathrm{Cu}^{\mathrm{II}}$ ion plays a role as well in the redox-mediated formation of reactive oxygen species. $^{32}$

The activation of molecular oxygen by a mononuclear $\mathrm{Cu}^{\mathrm{II}}$ complex in the presence of DNA is expected to lead to the abstraction of a proton/hydrogen from the sugar backbone or from the bulk solvent. This proton abstract may be accompanied by the binding of oxygen at a suitable free coordination site, if the coordination environment around the $\mathrm{Cu}^{\mathrm{II}}$ ion allows it. In the present complex, the ligand pbt coordinates as a bidentate ligand to the metal center, resulting in a five-membered chelating ring. The ensuing rigidity and planarity of the ligand favors its interaction with DNA by partial intercalation. In addition, the extensive $\pi$-delocalization in the ligand could potentially allow an electronic overlap with the nucleobases and the sugars, which enhances the acidic character of the sugar protons for an oxidative attack. Further evidence of dioxygen binding and transfer mediated by metal complexes with the ligand pbt have been described in the literature. For instance, the complex $\mathrm{Rh}(\mathrm{pbt}) \mathrm{Cl}_{3}$ is capable of activating dioxygen and transferring it for further chemical transformations. ${ }^{57}$ Moreover, the benzothiazole group of the ligand pbt resembles the DNA recognition unit of the natural anticancer drug bleomycin which also cleaves DNA through a self-activating mechanism in the presence of molecular oxygen. ${ }^{35}$ A related ligand, i.e., famotidine, is an antiulcer drug which leads to DNA damage in the presence of $\mathrm{Cu}^{\mathrm{II}}$ ions and which also acts as a catalyst for sulfite autoxidation in the presence of molecular oxygen. $^{58,59}$

As discussed above, the nondiffusible radicals produced upon dioxygen activation during the self-activated cleavage of DNA preclude the participation of unstable, metal-bound hydroxyl/peroxyl radicals or alkyl peroxyl radicals during the oxidative process. The presence of the sulfur atom in

(56) Bard, A. J.; Faulkner, L. R. Electrochemical Methods: Fundamental Applications; Wiley: New York, 1980; p 218.

(57) Gangopadhyay, J.; Sengupta, S.; Bhattacharyya, S.; Chakraborty, I.; Chakravorty, A. Inorg. Chem. 2002, 41, 2616-2622.

(58) Kubiak, M.; Duda, A. M.; Ganadu, M. L.; Kozlowski, H. J. Chem. Soc., Dalton Trans. 1996, 190, 5-1908.

(59) Muller, J. G.; Burrows, C. J. Inorg. Chim. Acta 1998, 276, 314-319. the ligand may facilitate back-bonding, thus favoring the formation of such metal-based highly reactive oxygen species, which leads to lesions in the DNA strands. The DNA-cleavage mechanism, albeit speculative, cannot be directly correlated to the in vivo cytotoxicity of the complex and the pure ligand. The pure ligand does not cleave $\phi \mathrm{X} 174$ phage DNA in vitro, but exhibits remarkable cytotoxic effects in the cancer cell lines comparable to complex $\mathbf{2}$ and cisplatin.

\section{Conclusions}

The efficient oxidative DNA cleavage mediated by the complex $\mathrm{Cu}(\mathrm{pbt}) \mathrm{Br}_{2}$ can be explained by a cooperative tetrahedral coordination environment associated to the intrinsic nature of the ligand pbt. In addition, the complex has labile bromide anions which can provide additional interaction sites for the binding and the interaction of both the biological substrate and the molecular oxygen. The redox behavior of the $\mathrm{Cu}(\mathrm{pbt}) \mathrm{Br}_{2}$ complex may in fact suggest a $\mathrm{Cu}^{\mathrm{III}}$-radical-mediated oxidative cleavage, initiated by the in situ activation of molecular oxygen. The occurrence of nondiffusible radicals suggests the involvement of metalsolvated radicals able to abstract protons from the deoxyribose sugar units of DNA, ultimately leading to its degradation. The free ligand pbt does not induce any DNA cleavage, but it exhibits efficient cytotoxicity against the selected cancer cells, comparable to that of $\mathrm{Cu}(\mathrm{pbt}) \mathrm{Br}_{2}$ and cisplatin.

In conclusion, the compound $\mathrm{Cu}(\mathrm{pbt}) \mathrm{Br}_{2}$ is an illustrative example for self-activated DNA damaging agents applicable in cancer chemotherapy, possibly targeting DNA and inducing apoptosis in the selected cancer cell lines.

\section{Experimental Section}

Synthesis of the Ligand 2-(2-Pyridyl)benzthiazole (pbt). The ligand was prepared and characterized as reported earlier. ${ }^{57}$

${ }^{1} \mathrm{H}$ NMR data: $\delta 8.68(\mathrm{~d}), 7.51(\mathrm{t}), 7.85(\mathrm{t}), 8.10(\mathrm{~d}), 8.37$ (d), $7.42(\mathrm{t}), 7.38(\mathrm{t}), 7.96(\mathrm{~d}) \mathrm{ppm}$. IR (neat, $\mathrm{cm}^{-1}$ ): $v 1585,1510$, 1456, 1435, 1317, 1235, 997, 979, 781, 739, 704, 620. Anal. Calcd for $\mathrm{C}_{12} \mathrm{H}_{8} \mathrm{~N}_{2} \mathrm{~S}$ (fw $=212.27 \mathrm{~g} \mathrm{~mol}^{-1}$ ): C, 67.89; H, 3.79; N, 13.20; S, 15.11. Found: C, 67.34; H, 3.75; N, 13.24; S, 14.06.

Synthesis of $\left[\mathbf{C u}(\mathbf{p b t}) \mathbf{B r}_{2}\right](\mathbf{1})$. The ligand $(0.5 \mathrm{mmol}, 0.106$ g) was dissolved in $10 \mathrm{~mL}$ of acetonitrile, and $0.5 \mathrm{mmol}$ of $\mathrm{CuBr}_{2}$ $(0.111 \mathrm{~g})$ in acetonitrile was added to the ligand solution dropwise under warm conditions. The resulting solution was filtered, and the filtrate was left unperturbed in air for the slow evaporation of the solvent. Dark-red crystals, suitable for X-ray analysis, were obtained after 1 day. Yield (based on the ligand) $=78 \%(17 \mathrm{mg})$. IR (neat, $\left.\mathrm{cm}^{-1}\right): v$ 2360, 1603, 1557, 1486, $1455,1305,1247,1155,1076,1008,882,764,728,711,647$, 623, 472, 435. Anal. Calcd for $\mathrm{C}_{12} \mathrm{H}_{8} \mathrm{Br}_{2} \mathrm{CuN}_{2} \mathrm{~S}$ ( $\mathrm{fw}=435.62 \mathrm{~g}$ $\mathrm{mol}^{-1}$ ): C, 33.08; H, 1.85; N, 6.43; S, 7.36. Found: C, 33.16; $\mathrm{H}, 1.74 ; \mathrm{N}, 6.58 ; \mathrm{S}, 7.59$. The powder EPR spectrum of complex 1 at RT and $70 \mathrm{~K}$ exhibits an unresolved axial signal with $g_{\|}=$ 2.24 and $g_{\perp}=2.08$. The frozen DMF solution $(70 \mathrm{~K})$ exhibits an isotropic signal with $g=2.11$.

Synthesis of $\left[\mathbf{C u}(\mathbf{p b t}) \mathrm{Br}_{2}(\mathbf{d m f})\right]$ (2). The ligand $(0.5 \mathrm{mmol}$, $0.106 \mathrm{~g}$ ) was dissolved in $5 \mathrm{~mL}$ of DMF, and $0.5 \mathrm{mmol}$ of $\mathrm{CuBr}_{2}$ $(0.111 \mathrm{~g})$ in DMF was added to the ligand solution dropwise under warm conditions. The resulting solution was left unperturbed at 
Maheswari et al.

Table 3. In Vitro Cytotoxicity Assays for Copper Complex 2, the Ligand pbt, and Cisplatin for Different Cancer Cell Lines

\begin{tabular}{|c|c|c|c|c|c|c|}
\hline \multirow[b]{2}{*}{ cell lines } & \multicolumn{2}{|c|}{$\left[\mathrm{Cu}(\mathrm{pbt}) \mathrm{Br}_{2}(\mathrm{dmf})\right]$} & \multicolumn{2}{|c|}{ pbt ligand } & \multicolumn{2}{|c|}{ cisplatin } \\
\hline & $\mathrm{IC}_{50}{ }^{a}$ (in $\left.\mu \mathrm{M}\right)$ & $\mathrm{RF}^{b}$ & $\mathrm{IC}_{50}{ }^{a}$ (in $\left.\mu \mathrm{M}\right)$ & $\mathrm{RF}$ & $\mathrm{IC}_{50}{ }^{a}($ in $\mu \mathrm{M})$ & $\mathrm{RF}^{b}$ \\
\hline L1210 & $8.6 \pm 0.2$ & $0.5 \pm 0.2$ & $3.4 \pm 0.2$ & $3.08 \pm 0.2$ & $2.3 \pm 0.3$ & $6.2 \pm 0.2$ \\
\hline A2780 & $6.2 \pm 0.2$ & $0.5 \pm 0.4$ & $4.1 \pm 0.3$ & $1.2 \pm 0.8$ & $2.3 \pm 0.2$ & $3.3 \pm 0.5$ \\
\hline A2780-R & $3.1 \pm 0.6$ & & $5.3 \pm 0.7$ & & $7.5 \pm 0.2$ & \\
\hline
\end{tabular}

${ }^{a} \mathrm{IC}_{50}=$ concentration of drug required to eradicate $50 \%$ of the cancer cells. ${ }^{b} \mathrm{RF}=$ relative ratios of $\mathrm{IC}_{50}$ values in both the cisplatin resistant and the sensitive cell lines.
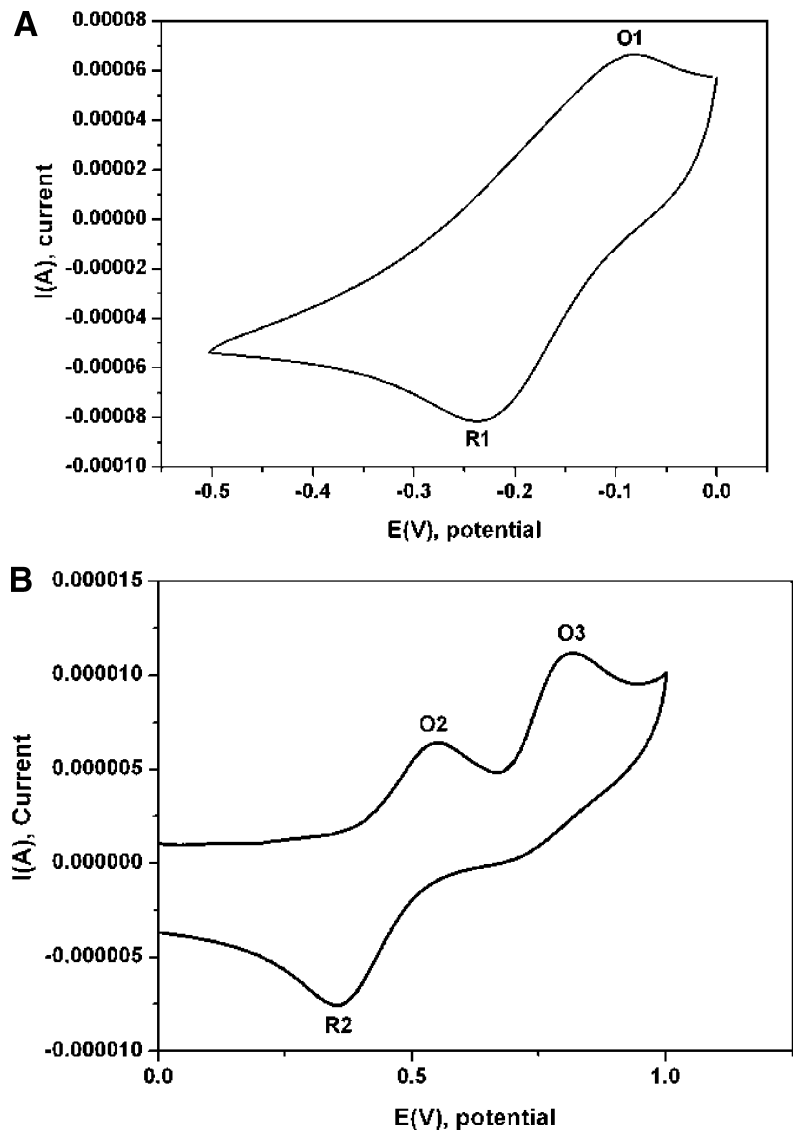

Figure 11. (A) Cyclic voltammogram of $0.001 \mathrm{M}$ complex 1 in DMF (cathodic scan, $100 \mathrm{mV} \mathrm{s}^{-1}$ ), at $\mathrm{RT}$, versus $\mathrm{Ag} / \mathrm{Ag}^{+}$. (B). Cyclic voltammogram of $0.001 \mathrm{M}$ complex 1 in DMF (anodic scan, $100 \mathrm{mV} \mathrm{s}^{-1}$ ), at RT, versus $\mathrm{Ag} / \mathrm{Ag}^{+}$.

$4{ }^{\circ} \mathrm{C}$ in a capillary EPR tube. After a month, light-green needleshaped crystals, suitable for X-ray diffraction, were obtained. The same compound was obtained by dissolving complex $\mathbf{1}$ in pure DMF, at $4{ }^{\circ} \mathrm{C}$.

Synthesis of $\left[\mathbf{Z n}(\mathbf{p b t}) \mathbf{C l}_{\mathbf{2}}\right]$ (3). The ligand (0.5 mmol, $\left.0.106 \mathrm{~g}\right)$ was dissolved in $10 \mathrm{~mL}$ of acetonitrile, and $0.5 \mathrm{mmol}(0.068 \mathrm{~g})$ of $\mathrm{ZnCl}_{2}$ in acetonitrile was added to the ligand dropwise under warm conditions, filtered, and kept for slow evaporation in air. Colorless crystals were obtained after 2 days. Yield (based on the ligand) $=$ $69 \%$ (12 mg). IR (neat, $\mathrm{cm}^{-1}$ ): $v$ 2360, 1603, 1486, 1325, 1246, 1158, 1029, 1011, 885, 786, 762, 727, 707, 643, 626. Anal. Calcd for $\mathrm{C}_{12} \mathrm{H}_{8} \mathrm{Cl}_{2} \mathrm{~N}_{2} \mathrm{SZn}\left(\mathrm{fw}=348.53 \mathrm{~g} \mathrm{~mol}^{-1}\right.$ ): $\mathrm{C}, 41.34 ; \mathrm{H}, 2.31 ; \mathrm{N}$, 8.03; S, 9.20. Found: C, 41.32, H, 2.14, N, 8.08; S, 8.15. The percent $\mathrm{S}$ deviatiation is relatively large, as we have regularly observed before for other metal complexes.

\section{Materials and Methods}

All chemicals were used as obtained without further purification. The solvents mentioned were dried prior to use. Elemental analyses
(C, H, N) were carried out on a Perkin-Elmer 2400 series II analyzer. FTIR spectra were recorded with a Perkin-Elmer Paragon 1000 FTIR spectrophotometer, equipped with a Golden Gate ATR device, using the reflectance technique (4000-300 $\left.\mathrm{cm}^{-1}\right) .{ }^{1} \mathrm{H}$ NMR spectra were recorded using a DPX 300 Bruker $(300 \mathrm{MHz}$ ) instrument. Chemical shifts are reported in ppm (parts per million) relative to the solvent peak. X-band EPR measurements were performed at $77 \mathrm{~K}$ in the solid state on a Jeol RE2x electron spin resonance spectrometer, using dpph $(g=2.0036)$ as a standard.

Cyclic Voltammetry (CV). The electrochemical behavior of complex 1 was investigated by means of $\mathrm{CV}$ in dimethylformamide (DMF) containing $0.1 \mathrm{M}\left(\mathrm{Bu}_{4} \mathrm{~N}\right) \mathrm{PF}_{6}$ as the supporting electrolyte. A three-electrode system containing a platinum-wire working electrode, a platinum-plate (counter) electrode, and an $\mathrm{Ag} / \mathrm{AgCl}$ reference electrode was used. The three electrodes were positioned as close as possible to minimize the Ohmic potential (IR) drop. Voltammetric recordings were performed under an argon atmosphere at RT. The concentration of the complex was $0.001 \mathrm{M}$ for each measurement, and the voltage scan rate was $100 \mathrm{mV} \mathrm{s}^{-1}$.

DNA Cleavage. $\phi$ X174 DNA was purchased from Invitrogen and stored at $-20{ }^{\circ} \mathrm{C}$. The typical reaction mixture, containing phage DNA and the copper complex 1 in a $10 \mathrm{mM}$ phosphate buffer solution ( $\mathrm{pH} 7.2$ ), was incubated at $37{ }^{\circ} \mathrm{C}$ for the required time, with or without additives. After the incubation period, the reaction was quenched at $-20{ }^{\circ} \mathrm{C}$, followed by the addition of loading buffer (bromophenol blue, xylene cyanol, and 25\% ficoll). This reaction mixture was then loaded on a $0.8 \%$ agarose gel containing ethidium bromide $(2.54 \mu \mathrm{M}$ final concentration in the gel as well as in the buffer). The gels were run at a constant voltage of $80 \mathrm{~V}$ for $60-90$ min in TBE buffer containing ethidium bromide. After washing with distilled water, the gels were visualized under a UV transilluminator and the bands were documented and quantified using a BioRad Gel Doc 1000 apparatus interfaced with a computer. As complex $\mathbf{1}$ is only highly soluble in DMF, the DNA cleavage and the cytotoxicity experiments were carried out in a buffer containing $2 \%$ DMF. The stock solutions were prepared in DMF, and the dilutions for the in vitro experiments were adjusted to obtain solutions containing less than 2\% DMF. In DMF, complex 1 turns immediately from dark-red to a light-green color, typical of complex 2. Both complexes $\mathbf{1}$ and $\mathbf{2}$ have similar DNA cleavage and cytotoxic properties.

Enzymatic Religation. pUC19 plasmid DNA was treated with complex 1, without any reductant, at $37{ }^{\circ} \mathrm{C}$ and at $\mathrm{pH}$ 7.2. DNA samples were purified over QIAquick PCR purification columns (Qiagen) and used for religation experiments. Control DNA was digested with endonuclease $P s t \mathrm{I}$ and cleaned in the same way. The ligation was performed in a $20 \mu \mathrm{L}$ range using $50 \mathrm{ng}$ of the digested DNA products with 2 units of T4 DNA ligase (Fermentas) for $16 \mathrm{~h}$ at $16^{\circ} \mathrm{C}$.

X-ray Crystallography. The molecular structures of complexes 1-3 were determined by single-crystal X-ray diffraction methods. Crystallographic data and refinement details are given in Table 2. 
Intensity data and cell parameters were recorded at RT on a Bruker AXS Smart 1000 single-crystal diffractometer (Mo K $\alpha$ radiation) equipped with a $C C D$ area detector. The data reductions were performed using the SAINT and SADABS programs. ${ }^{60}$ The structures were solved by direct methods using the SIR 97 program and ${ }^{61}$ refined on $F_{\mathrm{o}}{ }^{2}$ by full-matrix least-squares procedures, using the SHELXL-97 program. ${ }^{62}$ All nonhydrogen atoms were refined with anisotropic atomic displacements. The hydrogen atoms were found in the difference Fourier map with the exception of the $\mathrm{H}$ atoms of compound $\mathbf{3}$ and of the methyl groups of the DMF molecules in compound 2 , which were included in the refinement at idealized geometries $(\mathrm{C}-\mathrm{H} 0.95 \AA)$ and refined "riding" on the corresponding parent atoms. The weighting scheme used in the last cycle of refinement was $w=1 /\left[\sigma^{2} F_{\mathrm{o}}{ }^{2}+(0.0280 P)^{2}\right], w=1 /\left[\sigma^{2} F_{\mathrm{o}}{ }^{2}\right.$ $\left.+(0.0334 P)^{2}+6.9959 P\right]$, and $w=1 /\left[\sigma^{2} F_{\mathrm{o}}{ }^{2}+(0.0500 P)^{2}\right]$ (where $\left.P=\left(F_{\mathrm{o}}^{2}+2 F_{\mathrm{c}}^{2}\right) / 3\right)$ for $\mathbf{1}, \mathbf{2}$, and $\mathbf{3}$, respectively. Molecular geometry calculations were carried out using the PLATON package. ${ }^{63}$

Crystallographic data (excluding structure factors) for the structures reported have been deposited with the Cambridge Crystallographic Data Center as supplementary publication nos. CCDC 667533, 667534, and 667535 and can be obtained free of charge on application to the CCDC, 12 Union Road, Cambridge CB2 1EZ, U.K. (fax, (international) + 44-1223/336-033; e-mail, deposit@ccdc.cam.ac.uk).

Cytotoxicity Assays. The cell lines A2780 and A2780R, i.e., ovarian cancer cell lines derived from untreated patient cells ${ }^{64}$ which

(60) SAINT, Software Users guide, version 6.0. In Software Users Guide, version 6.0; Bruker Analytical X-ray Systems: Madison, WI, 1999. Sheldrick, G. M. SADABS, Area Detector Absorption Correction, version 2.03; University of Göttingen: Göttingen, Germany, 1999.

(61) Altomare, A; Burla, M. C.; Camalli, M.; Cascarano, G. L.; Giacovazzo, C.; Guagliardi, A.; Moliterni, A. G. G.; Polidori, G.; Spagna, R. J. Appl. Crystallogr. 1999, 32, 115-119.

(62) Sheldrick G. M. SHELXL-97. Program for Crystal Structure Refinement; University of Göttingen: Göttingen, Germany, 1997.

(63) Spek, A. L. PLATON. A Multipurpose Crystallographic Tool; Utrecht University: Utrecht, The Netherlands, 2003.

(64) Eva, A.; Robbins, K. C.; Andersen, P. R.; Srinivasan, A.; Tronick, S. R.; Reddy, E. P.; Ellmore, N. W.; Galen, A. T.; Lautenberger, J. A. Papas, T. S.; Westin, E. H.; Wong-Staal, F.; Gallo, R. C.; Aaronson, S. A. Nature 1982, 295, 116-119. survive in cultures treated with the compounds, were evaluated using the so-called MTT method. This method is based on the mitochondrial reduction of the tetrazolium salt MTT (2-(4,5dimethylthiazol-2-yl)-2,5-diphenyl-2H-tetrazolium bromide) by actively growing cells to produce blue insoluble purple formazan crystals. ${ }^{65}$ Both cell lines were cultured in DMEM (Hyclone, Logan, UT, U.S.A.) medium, supplemented with $10 \%$ fetal calf serum (Hyclone, Utah, U.S.A.), penicillin (100 units/ml), and streptomycin (100 $\mu \mathrm{g} / \mathrm{ml}$ ) (Duchefa, Netherlands). For the cell-growth assays, cells $(5.104 / \mathrm{mL})$ were precultured in 96 multiwell plates for $24 \mathrm{~h}$ at $37{ }^{\circ} \mathrm{C}, 5 \% \mathrm{CO}_{2}$. The compounds were added in microwells containing the cell culture at final concentrations of $0-200 \mu \mathrm{M}$. After $48 \mathrm{~h}$, the cell survival was evaluated by measuring the absorbance at $590 \mathrm{~nm}$, using a BIO-RAD microplate model 550. The $\mathrm{IC}_{50}$ values (i.e., the concentration of the complex that restricts cell growth to $50 \%$, compared with that of the control experiment) were calculated from the curves constructed by plotting the cell survival $(\%)$ versus the compound concentration $(\mu \mathrm{M})$. All experiments were performed in triplicate. The data were used for the construction of response curves and for the determination of the $\mathrm{IC}_{50}$ values using the GraphPad Prism software, version 3.0, 2000.

Acknowledgment. This research is financially supported by the Dutch Economy, Ecology and Technology (EET) program, a joint program of the Ministry of Economic Affairs, the Ministry of Education, Culture and Science, and the Ministry of Housing, Spatial Planning and the Environment. A VENI grant from The Netherlands Foundation for Science Research (NWO) to S.B. is gratefully acknowledged.

Supporting Information Available: Three supplementary figures with packing details. This material is available free of charge via the Internet at http://pubs.acs.org.

\section{IC702306F}

(65) Alley, M. C.; Scudiero, D. A.; Monks, A.; Hursey, M. L.; Czerwinski, M. J.; Fine, D. L.; Abboh, B. J.; Mayo, J. G.; Shoemaker, R. H.; Boyd, M. R. Cancer. Res. 1988, 48, 589-601. 